\title{
Angiotensin converting enzyme inhibitor suppresses glomerular transforming growth factor $\beta$ receptor expression in experimental diabetes in rats
}

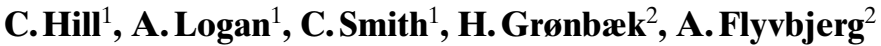 \\ ${ }^{1}$ Department of Medicine, University of Birmingham, Birmingham, UK \\ ${ }^{2}$ Medical Research Lab. M (Diabetes and Endocrinology), Institute of Experimental Clinical Research, University of Aarhus, \\ Aarhus, Denmark
}

\begin{abstract}
Aims/hypothesis. Activation of the renal transforming growth factor $\beta$ (TGF- $\beta$ ) axis has been suggested to play a part in the development of diabetic nephropathy by a direct stimulatory effect of hyperglycaemia or through the activation of the renin-angiotensin system. Our aim was to evaluate the involvement of the renin-angiotensin system by examining the effects of ACE-inhibition on intrarenal changes in all three TGF- $\beta$ isoforms and receptors in experimental diabetes in vivo.

Methods. Immunocytochemistry, western blotting and ribonuclease protection assays were carried out for each TGF- $\beta$ isoform and receptor on kidney from non-diabetic and streptozotocin-diabetic rats after treatment with the ACE inhibitor, enalapril, for 30 days.

Results. Enalapril partially prevented the renal hypertrophy and fully prevented the increase in urinary
\end{abstract}

albumin excretion rate in diabetic animals. The glomerular TGF- $\beta$ Type II Receptor mRNA and protein concentrations increased over 30 days in untreated diabetic animals compared with non-diabetic controls, while enalapril-treated diabetic animals showed a normalisation of TGF- $\beta$ Type II Receptor mRNA and protein.

Conclusion/interpretation. The ACE-inhibition had pronounced inhibitory effects on the increased expression of the glomerular TGF- $\beta$ Type II Receptor in the diabetic kidney required for intracellular signalling through this growth factor axis. This suggests a new mechanism of action of the ACE-inhibition in regulating the development of diabetic nephropathy. [Diabetologia (2001) 44: 495-500]

Keywords Enalapril, renin-angiotensin system, nephropathy, fibrosis, streptozotocin, diabetes.
The fibrogenic transforming growth factor $\beta$ (TGF- $\beta$ ) system [1-6] has, in addition to several other growth factor systems [7-8], been suggested to play a part in

Received: 4 August 2000 and in revised form: 11 December 2000

Corresponding author: Dr. Allan Flyvbjerg, MD, DMSc, Medical Department M/Medical Research Lab M, Institute of Experimental Clinical Research, University of Aarhus, Aarhus, DK-8000, Denmark

Abbreviations: ACEi, Angiotensin converting enzyme inhibitor; AT-1 receptor, Angiotensin type 1 receptor; mRNA, messenger RNA; RAS, renin-angiotensin system; TGF- $\beta$ RI, TGF- $\beta$ Type I Receptor; TGF- $\beta$ RII, TGF- $\beta$ Type II Receptor; TGF- $\beta$ RIII, TGF- $\beta$ Type III Receptor. the development of diabetic nephropathy. In vitro, high glucose concentrations increase TGF- $\beta 1$ messenger RNA (mRNA) concentrations in both cultured mesangial cells and proximal tubular cells [1, 2]. In addition, in vivo experiments have shown changes in the endogenous renal TGF- $\beta$ axis in various animal models of experimental diabetes [3-6]. It has been suggested that activation of the renal TGF- $\beta$ system in diabetes might be mediated, beside a direct stimulatory effect of hyperglycaemia in itself $[1,2]$, through activation of the renin-angiotensin system (RAS). Accordingly, exposure of mesangial cells in vitro to angiotensin II stimulates the expression of TGF- $\beta$ and extracellular matrix proteins [9]. Furthermore, one study examined the effect of an angio- 
tensin converting enzyme inhibitor (ACEi), captopril, on high-glucose induced changes in the TGF- $\beta$ system and growth in LLC-PK 1 cells in vitro, a porcine kidney cell line analogous to the proximal tubule cell [10]. In this cell system, high-glucose increased TGF- $\beta 1$ mRNA, TGF- $\beta$ Type I Receptor (TGF$\beta$ RI), TGF- $\beta$ Type II Receptor (TGF- $\beta$ RII) protein expression and cellular hypertrophy. Captopril dosedependently decreased TGF- $\beta$ RI and TGF- $\beta$ RII protein expression and cellular hypertrophy, increased cellular hyperplasia, whereas TGF- $\beta 1 \mathrm{mRNA}$ did not change [10]. So far, no published data have shown the possible effect of ACE-inhibition on the intrarenal changes in all the various TGF- $\beta$ isoforms (TGF$\beta 1,-2,-3)$ and TGF- $\beta$ RI, TGF- $\beta$ RII, TGF- $\beta$ Type III Receptor (TGF- $\beta$ RIII) in experimental diabetes in vivo. The aim of this study was to examine the effect of ACE-inhibition on the renal gene-expression and protein concentrationof all parameters of the TGF- $\beta$ axis in streptozotocin diabetic rats for 30 days.

\section{Methods}

Animals and protocol. Three groups of 12 adult female Wistar rats (Møllegaards Avlslab., Eiby, Denmark) with initial body weights of $190 \mathrm{~g}$ to $205 \mathrm{~g}$ were studied. Rats were housed three per cage in a room with $12: 12 \mathrm{~h}$ (06.00 to 18.00 hours) artificial light cycle, temperature $21 \pm 2{ }^{\circ} \mathrm{C}$ and humidity $55 \pm 2 \%$. The animals had free access to standard chow (Altromin \# 1324, Lage, Germany) throughout the experiment. The animals were randomised into three groups; two of these groups were made diabetic by an IV injection of streptozotocin (Upjohn Company, Kalamazoo, Mich., USA) in a dose of $50 \mathrm{mg} / \mathrm{kg}$ body weight, under light ether anaesthesia. Blood glucose was measured 1, 2, 3, 7,14 and 30 days after the streptozotocin injection into the tailvein by Haemoglucotest 1-44 and Reflolux II reflectance meter (Boehringer-Mannheim, Mannheim, Germany) and the urine tested for glucose and ketone bodies by Neostix-4 (Ames, Stoke Poges, Slough, UK). Only animals with blood glucose concentrations above $18 \mathrm{mmol} / \mathrm{l}$, urine glucose concentration above $111 \mathrm{mmol} / \mathrm{l}$ and without ketonuria were included in the study. One group of diabetic rats was treated with an ACEi, enalapril, via the drinking water at a concentration of $35 \mathrm{mg} / 1$ [11], another group was not treated and acted as diabetic controls. The third group was not treated and acted as non-diabetic controls. The ACEi treatment was initiated at the day of streptozotocin injection and lasted for the duration of the study.

One week before the experiment was initiated and at day 30 , the animals were placed in individual metabolic cages for $24 \mathrm{~h}$ urine collections [for measurement of urinary glucose, and urinary albumin excretion rate (AER)] and for measurements of food consumption. In addition, body weight was recorded. At the end of the study the animals were anaesthetised with sodium barbital (50 mg/kg body weight) and the left kidneys were rapidly removed and carefully cleaned, weighed and snap-frozen in liquid nitrogen.

Urinary AER. The urinary albumin concentration in $24 \mathrm{~h}$ urine collections was measured by radioimmunoassay [12] using rat albumin antibody and standards.

Blood pressure measurements. Blood pressures were measured in conscious animals at day 30 using the tail cuff method.
Antibodies. Antibodies and control peptides for the TGF- $\beta 1$, TGF- $\beta 3$, TGF- $\beta$ RII and TGF- $\beta$ RIII isoforms and receptors were purchased from R \& D Systems (Abingdon, Oxford, UK). The antibody against TGF- $\beta 2$ and its control peptides were a gift from Cambridge Antibody Technology (Melbourn, Cambridge., UK) and the antibody and control peptide for TGF- $\beta$ RI were purchased from Santa Cruz Biotechnology (Santa Cruz, Calif., USA). All biotinylated secondary antibodies were purchased from Vector Laboratories (Peterborough, Cambridge, UK) and all peroxidase conjugated secondary antibodies were purchased from Santa Cruz Biotechnology. The antibody against procollagen-I C-propeptide was a gift from Zeneca Pharmaceuticals (Macclesfield, Cheshire, UK).

Probes. Specific TGF- $\beta 1$ cRNA probes were constructed from a 985 kb TGF- 31 cDNA template (gift from Dr. M. Sporn, then at NIH, Bethesda, Md., USA), representing the major coding sequence of the TGF- $\beta 1$ precursor and subcloned into pBluescript SK + plasmid. The rat TGF- $\beta$ RII cDNA fragment (a gift from Dr W. Vale, La Jolla, Calif., USA) was cut to 455 bp in length and subcloned into psp73. Plasmids were linearised using restriction enzymes (Gibco-BRL Paisley, UK or Promega, Southampton, UK). All other reagents not specified were analytical grade from Sigma Chemical (Poole, Dorset, UK).

Immunocytochemistry. For each antibody used immunocytochemistry was done on kidney sections from at least 3 animals from each group. The sections were washed and treated briefly with protease (Sigma, Dorset, UK) and subjected to overnight incubation in the primary antibody at $4{ }^{\circ} \mathrm{C}$. The sections were washed and subjected to the secondary horse radish peroxidase linked antibody and the ABC method of substrate detection was used (Vector Labs, Peterborough, UK). The immunoreactvity in glomeruli was semi-quantified giving it a score from \pm to,+++ \pm being very little immunoreactivity and +++ being the strongest immunoreactivity noted. This analysis was done in a blind and randomised way for all the TGF- $\beta$ isoforms and receptors on at least 10 glomeruli per kidney section, on two kidney sections from each animal and in four animals per group [6].

Western blotting. Western blots were carried out on kidney cortex from at least 3 animals from each group and repeated 3 times for each antibody used. Protein $(100 \mu \mathrm{g})$ extracted from kidney cortex was loaded in each lane of the gels. A $12 \%$ polyacrylamide gel was run and blotted onto polyvinylidine flouride (PVDF) membrane (Biorad, Hertfordshire, UK). The membrane was incubated overnight with the primary antibody and further incubated with a horseradish peroxidase labelled secondary antibody and then detected using ECL (Amersham, Buckinghamshire, UK). The detailed method for protein extraction, protein quantification and Western blotting was previously described elsewhere [6].

Ribonuclease protection assay. Ribonuclease protection assays were done for TGF- $\beta 1$ and TGF- $\beta$ RII on at least 3 animals from each group on extracted total RNA from cortical kidney samples. The RNA extraction was done by RNAzol method (Biogenesis, Poole, Dorset, UK). The ribonuclease protection assay protocols have been described previously [6]. Radiolabelled riboprobes were synthesised for TGF- $\beta 1$ and TGF- $\beta$ RII and hybridised with each sample. These were then run on a $4 \%$ polyacrylamide $/ 8 \mathrm{~mol} / \mathrm{l}$ urea gel, dried and visualised on Hyperfilm (Amersham International, Buckinghamshire, UK) after 3 days.

Densitometric and statistical analysis. Autoradiographs were scanned into an Apple Macintosh computer. Densitometric 


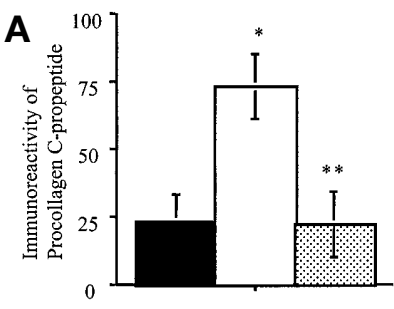

B
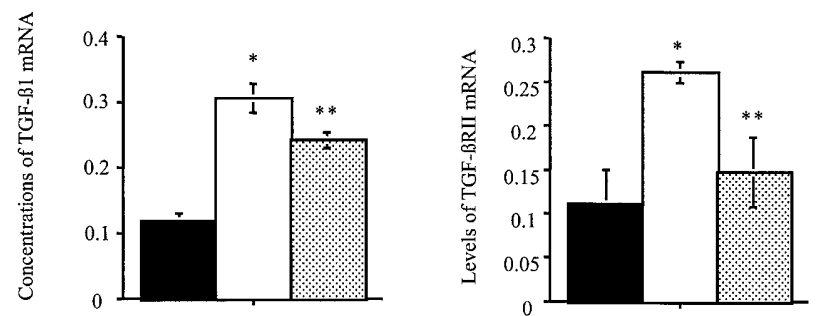

Fig. 1A-C. Data for procollagen-I C-propeptide (A), TGF- $\beta$ Type II Receptor (TGF- $\beta$ RII) protein (B) and TGF- $\beta$ RII mRNA (C) at day 30. Black solid bars: non-diabetic controls; white solid bars: placebo-treated diabetic rats; grey bars: enalapril-treated diabetic rats. All densitometry in arbitrary units \pm SEM. $n=3$. ${ }^{*} p<0.05$, placebo-treated diabetic rats vs nondiabetic control rats; $* * p<0.05$, enalapril-treated diabetic rats vs placebo-treated diabetic rats

analysis of the TGF- $\beta /$ receptors/collagen-I C-Propeptide bands in each sample in the western blots and the TGF- $\beta 1$ and TGF- $\beta$ RII bands in the RPA was carried out using NIH image $1.55 \mathrm{f}$ software (NIH shareware, Calif., USA). The density of each band was assigned a relative value, given in arbitrary units definied by the software. One way ANOVA was carried out on the densitometry results obtained to find which increases were statistically significant when compared with controls. A $p$ value of less than 0.05 was regarded as significant.

\section{Results}

Metabolic parameters, body weight and blood pressure. Over the 30 day experiment, the placebo and enalapril treated diabetic rats remained hyperglycaemic with blood glucose concentrations around $25 \mathrm{mmol} / \mathrm{l}$ (Table 1). The body weight measurements showed both diabetic groups had growth retardation and hyperphagia when compared with non-diabetic rats (Table 1). Enalapril treatment reduced blood pressure in the diabetic rats significantly compared with the untreated diabetic rats (Table 1).

Changes in kidney weight and urinary AER. Enalapril partially prevented the diabetes associated renal hypertrophy. In addition, the diabetes associated increase in AER was fully prevented by enalapril $(p<0.05$, Table 1$)$.

Changes in procollagen-I C-propeptide. Western blotting was carried out on protein from homogenized rat kidney cortex (Fig.1). Immunoreactivity of procollagen-I C-propeptide increased approximately threefold from non-diabetic control concentrations to diabetic day 30 ( $p<0.05$, when diabetic rats were compared with non-diabetic control rats). This increase was virtually abolished by the treatment of diabetics for 30 days with enalapril $(p<0.05$, when diabetic rats treated with enalapril were compared with untreated diabetic rats at day 30 ).

Changes in renal TGF- $\beta$ isoforms and receptors. The most marked change was found in the glomerular TGF- $\beta$ RII immunoreactivity, which increased over 30 days in untreated animals when compared with non-diabetic control animals, whereas enalapril therapy in diabetic animals was associated with a dramatic decrease in TGF- $\beta$ RII protein over 30 days to almost undetectable concentrations (Fig. 2). The changes in TGF- $\beta$ RII immunoreactivity were confirmed by western blotting (Fig.1). Immunoreactivity of TGF- $\beta$ RII increased approximately fourfold from non-diabetic control concentrations to diabetic day $30(p<0.05$ diabetic rats compared with non-diabetic control rats). This increase was fully abolished by enalapril treatment $(p=0.037$, when diabetic rats treated with enalapril were compared with untreated diabetic rats at day 30 ). Ribonuclease protection assays were done to identify changes in TGF- $\beta$ RII and TGF- $\beta 1$ mRNAs. An increase in TGF- $\beta 1$ mRNA was seen in diabetic rats compared with control rats. The diabetic rats treated with enalapril showed a decreased expression of TGF- $\beta 1$ mRNA compared
Table 1. Blood glucose, body weight, food consumption, blood pressure, kidney weight and urinary albumin excretion rate (AER) in non-diabetic control rats, placebo-treated diabetic rats and ACEi (enalapril)-diabetic rats at day 30. Data are giv- en as means \pm SEM. $n=12 .{ }^{\mathrm{a}} p<0.05$, non diabetic control rats vs diabetic rats, ${ }^{\mathrm{b}} p<0.05$, placebo-treated diabetic rats vs enalapril-treated diabetic rats

\begin{tabular}{lccr}
\hline Parameter $( \pm$ SEM) & Control Rats & Diabetic Rats & Treated Diabetic Rats \\
\hline Blood Glucose $(\mathrm{mmol} / \mathrm{l})$ & $5.7 \pm 0.4$ & $26.1 \pm 0.8^{\mathrm{a}}$ & $24.7 \pm 1.8^{\mathrm{a}}$ \\
Body Weight $(\mathrm{g})$ & $249.0 \pm 3.3$ & $236.3 \pm 3.9^{\mathrm{a}}$ & $232.2 \pm 4.3^{\mathrm{a}}$ \\
Food Consumption $(\mathrm{g} / 24 \mathrm{~h})$ & $19 \pm 2$ & $36 \pm 4^{\mathrm{a}}$ & $35 \pm 4^{\mathrm{a}}$ \\
Blood Pressure $(\mathrm{mmHg})$ & $109 \pm 2$ & $108 \pm 1$ & $94 \pm 1^{\mathrm{ab}}$ \\
Kidney Weight $(\mathrm{mg})$ & $761 \pm 6.7$ & $1069 \pm 30^{\mathrm{a}}$ & $968 \pm 14^{\mathrm{b}}$ \\
UAE $(\mu \mathrm{g} / 24 \mathrm{~h})$ & $92 \pm 15$ & $645 \pm 79^{\mathrm{a}}$ & $146 \pm 26^{\mathrm{b}}$ \\
\hline
\end{tabular}





Fig. 2A-C. Immunoreactivity of TGF- $\beta$ RII in glomeruli of non-diabetic control rats (A), placebo-treated diabetic rats after 30 days (B), and diabetic rats after 30 days of hyperglycaemia treated with enalapril $(\mathbf{C})$

A

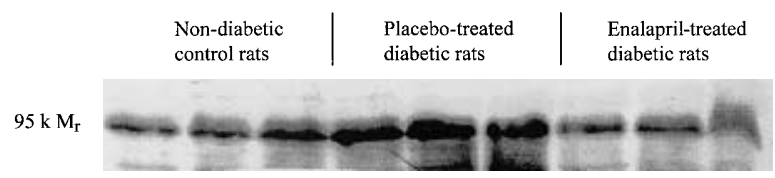

B

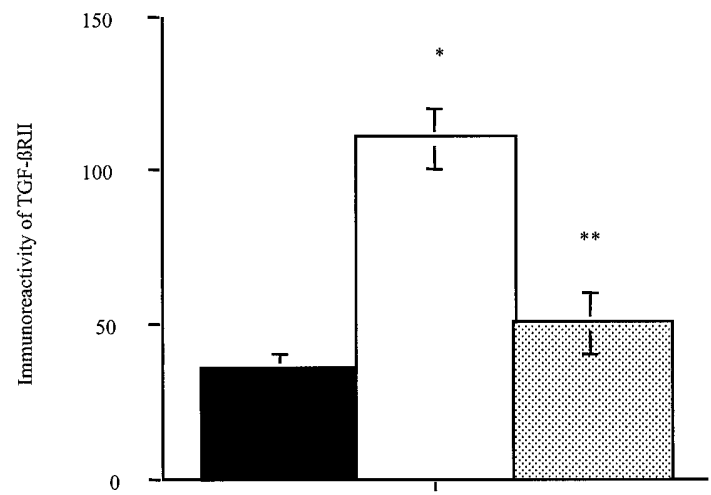

Fig. 3A, B. Data for TGF- $\beta$ Receptor II (TGF- $\beta$ RII) protein at day 30. (A) A representative western blot of the $95 \mathrm{kMr}$ TGF- $\beta$ RII. (B) Black solid bars: non-diabetic controls rats; white solid bars: placebo-treated diabetic rats; grey bars: enalapril-treated diabetic rats. All densitometry data are in arbitrary units \pm SEM. $n=3 .{ }^{*} p<0.05$, non-diabetic controls rats vs placebo treated diabetic rats; $* * p=0.037$, enalapril-treated diabetic rats vs placebo-treated diabetic rats

with untreated diabetic rats (Fig.1). An increase in TGF- $\beta$ RII mRNA was observed in the diabetic rats after 30 days compared with non-diabetic rats (Fig.1). This increase was markedly decreased at day 30 in the diabetic rats which had been treated with enalapril $(p<0.05$, when diabetic rats treated with enalapril were compared with untreated diabetic rats at day 30; Fig. 1 ).

\section{Discussion}

The TGF- $\beta$ is a prominent member of a family of cell regulatory proteins and is unique among growth factors in its broad effects on extracellular matrix. The kidney both produces TGF- $\beta$ and is a target of TGF$\beta$ action as TGF- $\beta$ mRNA, the active protein and TGF- $\beta$ receptors have all been shown in all cell types of the glomerulus $[6,15-17]$ and in proximal tubule renal cells $[2,18]$. In vitro, TGF- $\beta$ has been shown to modulate extracellular matrix production [19]. Of relevance, both glomerular mesangial and epithelial cells increase synthesis of extracellular matrix proteins including proteoglycans, fibronectin, type IV collagen and laminin in response to TGF- $\beta$ [20]. In addition, TGF- $\beta$ inhibits the synthesis of collagenases and stimulates tissue production of metalloproteinase inhibitors [21-23]. Together, these mechanisms could lead to increased production and reduced degradation of the extracellular matrix, thereby contributing to matrix accumulation.

A previous study examined the effect of an ACEi (captopril) on high-glucose induced changes in the TGF- $\beta$ system and growth in LLC-PK ${ }_{1}$ cells, a porcine kidney cell line analogous to the proximal tubule cell [9]. In this cell system, high-glucose increased TGF- $\beta 1$ mRNA, TGF- $\beta$ RI and TGF- $\beta$ RII protein expression and cellular hypertrophy. Captopril dosedependently decreased TGF- $\beta$ RI and TGF- $\beta$ RII protein expression and cellular hypertrophy, whereas TGF- $\beta 1$ mRNA did not change [10]. These findings indicate a direct effect of ACEi on the TGF- $\beta$ growth factor system. Another study examined the effects of ramipril in vivo on diabetic rats but only looked at the changes in TGF- $\beta 1 \mathrm{mRNA}$ and protein in the tubulointerstitium of rat kidney and not the glomeruli. This group showed that TGF- $\beta 1$ mRNA increased in the diabetic group but decreased in the diabetic group treated with ramipril [24]. Two clinical studies have dealt with changes in the renal expression of the TGF- $\beta$ system $[25,26]$. Initially increased TGF- $\beta$ immunostaining was described in glomeruli obtained from diabetic subjects [25]. This observation confirmed that increased concentrations of all three TGF- $\beta$ isoforms were reported in diabetic nephropa- 
Table 2. Glomerular immunoreactivity of the TGF- $\beta$ isoforms and receptors in non-diabetic control rats, placebo-treated diabetic rats and enalapril-treated diabetic rats at day $30 .+++$ : strong immunoreactivity, ++ : moderate immunoreactivity, + : weak immunoreactivity, \pm : very little immunoreactivity and -: absent immunoreactivity

\begin{tabular}{llll}
\hline Isoform & Control Rats & Diabetic Rats & $\begin{array}{l}\text { Treated } \\
\text { Diabetic Rats }\end{array}$ \\
\hline TGF- $\beta 1$ & + & ++ & + \\
TGF- $\beta 2$ & ++ & +++ & ++ \\
TGF- $\beta 3$ & ++ & +++ & ++ \\
TGF- $\beta$ RI & ++ & +++ & ++ \\
TGF- $\beta$ RII & +++ & +++ & \pm \\
TGF- $\beta$ RIII & ++ & ++ & + \\
\hline
\end{tabular}

thy [23]. These studies support the hypothesis that the glucose induced rise in renal TGF- $\beta$ expression and peptide in the kidney are responsible for some of the renal changes that follow the development of diabetic nephropathy.

Our laboratories have recently reported the changes in the entire TGF- $\beta$ axis in streptozotocin induced untreated diabetic rats throughout a 180 day time period and showed increased concentrations of TGF- $\beta 2$ and TGF- $\beta$ RII [6]. That study also described how the diabetic rat treated with streptozotocin is a representative in vivo model of the early clinical stages of diabetic nephropathy [6]. The diabetic animals treated with enalapril showed a reduced blood pressure and urinary AER. We characterized fibrosis by western blotting for the pro-collagen-I C-propeptide. This antibody was previously used in [6] as an indicator of fibrosis. Western blotting for procollagen-I C-propeptide showed that diabetic rats treated with enalapril had decreased concentrations of procollagen-I in their kidneys than did untreated diabetic rats. Together with the blood pressure and urinary AER data, these results clearly indicate the well-known renoprotective effect of enalapril.

As described previously in the streptozotocin-diabetic rat model, the TGF- $\beta$ axis changed markedly during the acute phase of diabetes [6]. In our study, similar changes were observed in diabetic rat kidneys. Enalapril treatment of diabetic rats resulted in weak suppression of the glomerular response of all TGF- $\beta$ isoforms during diabetes induction. This was reflected in the suppression of their mRNA concentrations. Thus, renal TGF- $\beta 1$ mRNA expression, which was increased in the diabetic rat decreased upon their treatment with enalapril.

We found that enalapril treatment had marked effects on the diabetes induced TGF- $\beta$ receptor changes. Specifically, glomerular TGF- $\beta$ RI and, more dramatically, TGF- $\beta$ RII immunostaining decreased at day 30 in the diabetic animals treated with enalapril compared with the untreated diabetic animals. This observation was confirmed by Western blotting of the TGF- $\beta$ RII receptor. This result shows the impor- tant role of TGF- $\beta$ RII in the TGF- $\beta$ signalling pathway. The TGF- $\beta$ RII is a constitutively active serinethreonine kinase [26]. When a TGF- $\beta$ isoform binds to TGF- $\beta$ RII, it recruits the TGF- $\beta$ RI and further phosphorylates it, which in turn starts the signalling cascade to the nucleus through the Smad proteins $[26,27]$. Accordingly, a decrease in TGF- $\beta$ RII protein expression will cause a decrease in TGF- $\beta$ signalling to the nucleus regardless of the number of ligands available and, consequently, less fibrosis can occur.

Other groups have also seen beneficial effects of ACEi (cilazapril), modulating the effects of the TGF- $\beta$ axis in the progression of glomerulonephritis into end stage renal failure in rats. The ACEi modulated the effects of angiotensin II, through the angiotensin type 1 receptor (AT-1), on the production of TGF- $\beta$ and collagens type I and III. This activity was additional to the effects on intrarenal haemodynamics, but was not achieved by increasing bradykinin activity or reducing blood pressure in this rat model [28]. The AT-1 receptor for angiotensin II has been blocked in many previous experiments [28, 29]. They have been shown to block angiotensin II synthesis in animal models of renal injury including diabetic nephropathy [30]. When rats were treated with AT-1 receptor blockers, there was a potent anti-proliferative effect and preserved glomerular and tubular structural integrity. Also, renal gene expression of TGF- $\beta 1$ and extracellular matrix protein was effectively reduced by these treatments [28, 29]. Therefore, blocking the synthesis of angiotensin II has a major part in preserving the kidney from fibrosis. We cannot rule out the bradykinin pathway in mediating the effects reported here. This avenue of investigation is currently being studied to see if the TGF$\beta$ axis is modulated by AT- 1 receptor inhibitors with a similar pattern to that seen when an ACEi is used. Finally, in a recent clinical study, captopril-treatment for 6 months in patients with Type I (insulin-dependent) diabetes mellitus patients lowered serum TGF- $\beta 1$ concentrations by approximately $20 \%$, whereas a slight increase was seen in placebo-treated patients [31]. Furthermore, the captopril-induced fall in serum TGF- $\beta 1$ correlated with the ACEi-induced stabilization of glomerular filtration rate over a 2 year period in patients with overt nephropathy [31].

In conclusion, our data suggests that the TGF- $\beta$ axis operates through a complex intra-renal system and could thus serve as a major mediator of the renal changes observed in experimental diabetes. Moreover, ACE-inhibition has pronounced inhibitory effects on the increased concentrations of the TGF- $\beta$ receptors required for intracellular signalling through this growth factor system [26].

Acknowledgements. This study was supported by grants from the Danish Medical Research Council (\# 9700592), the Danish Diabetes Association, the Danish Kidney Foundation, the 
Ruth König Petersen Foundation, the Novo Foundation, the Aage Louis-Hansen Memorial Foundation, the Nordic Insulin Foundation and the Aarhus University-Novo Nordisk Center for Research in Growth and Regeneration (\# 9600822) and the Department of Medicine, University of Birmingham, United Kingdom. We are grateful to K. Mathiassen, K. Nyborg and N. Rosenqvist for their excellent technical assistance.

\section{References}

1. Ziyadeh FN, Chen Y, Davila A, Goldfarb S (1992) Self limited stimulation of mesangial cell growth in high glucose: autocrine activation of TGF- $\beta$ reduces proliferation but increases mesangial matrix. Kidney Int 42: 647-656

2. Rocco MV, Chen Y, Goldfarb S, Ziyadeh FN (1992) Elevated glucose stimulates TGF- $\beta$ gene expression and bioactivity in proximal tubules. Kidney Int 41: 107-114

3. Shankland SJ, Scholey JW (1994) Expression of transforming growth factor $\beta 1$ during diabetic renal hypertrophy. Kidney Int 46: 430-442

4. Sharma K, Ziyadeh FN (1994) Renal hypertrophy is associated with upregulation of TGF- $\beta 1$ gene expression in diabetic BB rat and NOD mouse. Am J Physiol 67: F1094F1101

5. Pankewycz OG, Guan JX, Kline-Bolton W, Gomez A, Benedict JF (1994) Renal TGF- $\beta$ regulation in spontaneously diabetic NOD mice with correlations in mesangial cells. Kidney Int 46: 748-758

6. Hill C, Flyvbjerg A, Grønbæk H et al. (2000) The expression of transforming growth factor $\beta$ isoforms and their receptors in acute and chronic experimental diabetes in rats. Endocrinology 141: 1196-1208

7. Flyvbjerg A (1997) Role of growth hormone, insulin-like growth factors (IGFs) and IGF-binding proteins in the renal complications of diabetes. Kidney Int 52: S12-S19

8. Flyvbjerg A (2000) Putative pathophysiological Role of growth factors and cytokines in experimental diabetic kidney disease. Diabetologia 43: 1205-1223

9. Kagami S, Border WA, Miller DE, Noble NA (1994) Angiotensin II stimulates extracellular matrix protein synthesis through induction of transforming growth factor- $\beta$ expression in rat glomerular mesangial cells. J Clin Invest 93: 2431-2437

10. Guh JY, Yang ML, Yang YL, Chang CC, Chuang LY (1996) Captopril reverses high-glucose-induced growth effects on LLC-PK ${ }_{1}$ cells partly by decreasing transforming growth factor- $\beta$ receptor protein expression. J Am Soc Nephrol 7: 1207-1215

11. Cooper M, Allen TJ, Macmillan PA, Clarke BE, Jerums G, Doyle AE (1989) Enalapril retards glomerular basement membrane thickening and albuminuria in the diabetic rat. Diabetologia 32: 326-328

12. Flyvbjerg A, Marshall SM, Frystyk J, Hansen KW, Harris AG, Ørskov H (1992) Ocreotide administration in diabetic rats: effect on renal hypertrophy and urinary albumin excretion. Kidney Int 41: 805-812

13. Nakamura T, Fukui M, Ebihara E et al. (1993) mRNA expression of growth factors in glomeruli from diabetic rats. Diabetes 42: 450-456

14. Ziyadeh FN, Chen Y, Davila A, Goldfarb S (1992) Self limited stimulation of mesangial cell growth in high glucose: autocrine activation of TGF- $\beta$ reduces proliferation but increases mesangial matrix. Kidney Int 42: 647-656
15. Choi ME, Eung-Gook K, Ballerman BJ (1993) Rat mesangial cell hypertrophy in response to transforming growth factor $\beta 1$. Kidney Int 44: 948-958

16. Ziyadeh FN, Snipes ER, Watanabe M, Alvarey RJ, Goldfarb S, Haverty TP (1990) High glucose induces cell hypertrophy and stimulates collagen gene transcription in proximal tubule. Am J Physiol 259: F704-F714

17. Nakamura T, Miller D, Rouslahti E, Border WA (1992) Production of extracellular matrix by glomerular epithelial cells is regulated by transforming growth factor $\beta 1$. Kidney Int 41: 1213-1221

18. Humes HD, Nakamura T, Cieslinski DA, Miller D, Emmons RV, Border WA (1993) Part of protoglycans and cytoskeleton in the effects of TGF- $\beta 1$ on renal proximal tubule cells. Kidney Int 43: 575-584

19. Roberts AB, McCune BK, Sporn MB (1992) TGF- $\beta 1$ : Regulation of extracellular matrix. Kidney Int 41: 557-559

20. Davies M, Thomas GJ, Martin J, Lovett DH (1988) The purification and characterisation of a glomerular basement membrane degrading neutral proteinase from the rat mesangial cells. Biochem J 251: 419-425

21. Marti HP, Lee L, Kashgarian M, Lovett DH (1994) Transforming growth factor $\beta 1$ stimulates mesangial cell synthesis of the $72 \mathrm{kD}$ type IV collagenase. Am J Pathol 144: 82-94

22. Yamamoto T, Nakamura T, Noble NA, Ruoslahti E, Border WA (1993) Expression of transforming growth factor is elevated in human and experimental diabetic glomerulopathy. Proc Natl Acad Sci USA 90: 1814-1818

23. Yamamoto T, Noble NA, Cohen AH et al. (1996) Expression of transforming growth factor- $\beta$ isoforms in human glomerular diseases. Kidney Int 49: 461-469

24. Gilbert RE, Cox A, Wu LL et al. (1998) Expression of transforming growth factor- $\beta 1$ and type IV collagen in the renal tubulointerstitium in experimental diabetes: Effects of angiotensin converting enzyme inhibition. Diabetes 47: 414-422

25. Hu PP, Datto MB, Wang XF (1998) Molecular mechanisms of transforming growth factor- $\beta$ signalling. Endocr Rev 19: 349-363

26. Wrana JL, Attisano L, Wieser R, Ventura F, Massague J (1994) Mechanism of activation of the TGF- $\beta$ receptor. Nature 370: 341-347

27. Nakamura T, Obata J, Kimura H et al. (1999) Blocking angiotensin II ameliorates proteinuria and glomerular lesions in progressive mesangioproliferative glomerulonephritis. Kidney Int 55: 877-889

28. Zoja C, Donodelli R, Coma D et al. (1997) The renoprotective properties of angiotensin converting enzyme inhibitors in a chronic model of membraneous nephropathy are solely due to the inhibition of angiotensin II: Evidence based on competitive studies with a receptor antagonist. Am J Kidney Dis 29: 254-264

29. Klahr S, Ishidoya S, Morrissey J (1995) Part of angiotensin II in the tubulointerstitial fibrosis of obstructive nephropathy. Am J Kidney Dis 26: 141-146

30. Remuzzi A, Fassi A, Sangalli F et al. (1998) Prevention of renal injury in diabetic MWF rats by angiotensin II antagonism. Exp Nephrol 6: 28-38

31. Sharma K, Eltayeb BO, McGowan TA et al. (1999) Captopril-induced reduction in serum TGF- $\beta 1$ correlates with long-term renoprotection in insulin-dependent diabetic patients. Am J Kidney Dis 34: 818-823 